change in direction, whether the command comes from a genius or from a mediocrity. They can be accelerated slightly be leaders of great drive, and lose momentum without leadership. But invariably they grind on remorselessly, very inefficiently, but necessarily successfully, for only mass murder could stop them in their tracks. to derive job satisfaction from the awareness that, without one's sustained efforts over a year, the organisation would be moving in a slightly different direction, and would not have got quite so far. Such a form of sophistication Dyson does not have. To him only work in a small group is
It needs a certain type of sophistication

fun. This attitude separates him from much modern engineering and from much that is involved in the public service. He is thus a supporter of small bands of pioneers rather than of large project management teams. It is a great loss that our necessarily large bureaucracies are unable to attract such talent.

I am sure I have said enough to make it clear that I thoroughly enjoyed reading this book, that it gave me a lot to think about, and that I can recommend it heartily to all.

Sir Hermann Bondi is Chief Scientist at Her Majesty's Government's Department of Energy.

\section{A man who thinks otherwise}

\section{Eric Ashby}

The Medusa and the Snail: More Notes of a Biology Watcher. By Lewis Thomas. Pp. 175. (Viking: New York, 1979.) \$8.95 (A UK edition will be published after May next year by Allen Lane (Lrondon).)

IN far off days, when the academic profession was a revered élite, the Germans defined a professor as "a man who thinks otherwise". In these days, when knowledge is fragmented and the academic profession unionised, otherwise-thinking is rare, even among professors. Hence the significance of this little book of essays, for Lewis Thomas is a virtuoso in thinking otherwise.

At first glance the book seems to be lightweight, no more than a capricious assortment of fancies about ponds in Manhattan, cloning of human beings, committees, punctuation, disease, death, warts; all gently mischievous, witty, conversational in style, the work of a latter day Montaigne or Lamb. Those who have read Thomas' other essays (The Lives of a Cell: Notes of a Biology Watcher; Viking: New York; Garnstone: Petworth, UK; for review, see Nature, 258, 24; 1975), know how misleading such a first glance would be. In common with another Lewis, Lewis Carroll, he has an extraordinary intellectual exuberance. I have not read any of his papers on pathology (Thomas is a distinguished pathologist) but I guess they are as unlike The Medusa and the Snail as Lewis Carroll's Euclid and his Modern Rivals, published just 100 years ago, is unlike The Hunting of the Snark.

Carroll wrote for children. Thomas writes for grown-ups who still retain a child's capacity for wonder. Apart from his mastery of prose, which makes me green with envy, he has a rare talent for picking up something familiar and suddenly, with a flash of imagination, giving it a fresh meaning. It's done deftly, like a conjuring trick. It's the technique of a poet. Edith Sitwell used it effectively; she described it once to me as a "leakage of thought" from one compartment of the mind to another. Thomas himself describes it: "finding the marks of remote similarity, points of distant relationship, tiny irregularities that indicate that this one is really the same as that one over there only more important". And in an essay on thinking about thinking he tries to describe the process. The human head, he writes, "is filled alive with molecules of thought called notions. . flowing at random from place to place, bumping against each other...like the paths of Brownian movement"'. The mind is heated a little, the movement speeds up, there are more encounters, some of the notions dock and lock (notice the imagery of space-travel), aggregates are formed, they act like "purposeful organisms, hunting for new things to fit with. . turning things over, catching at everything" - and a harmonious idea is generated, with the elegant geometry of a Brandenburg concerto. At that point Thomas' mind takes another leap: why not begin with music "and see what this can tell us about the sensation of thinking".

So far so good: the book is delightful believe it is. It is a piece of intellectual autobiography. Its theme is the impact of Nature on Lewis Thomas. By what I believe is a valid extrapolation, it speaks for thousands of other less articulate biologists and naturalists; and this is why it is more than entertainment. Thomas visits the Tucson Zoo and watches beavers and otters at play in glass-walled pools. For a few minutes he sheds his professional reductionist shell and becomes, as he puts it, "transfixed. . there was only one sensation in my head: pure elation mixed with amazement at such perfection". The beavers and otters had done something to entertainment. Is it more than that? I him. "I learned nothing new about them. Only about me, and I suspect also about you, maybe about human beings at large: we are endowed with genes which code out our reaction to beavers and otters, maybe [my italics] our reaction to each other as well'".

Speculation, bordering on the turbulent territory of sociobiology? Perhaps it is, but there is no dogmatic assertion in Thomas' reflections. He offers you a subjective experience, take it or leave it. I would be surprised if many biologists reject the credo which is the main motif in these essays. The credo rests on wonder at two principles Thomas finds all around him. One is uniqueness; the other is symbiosis. Here are a few examples of the impact they make on him.

To say that the DNA molecule is the greatest single achievement of Nature is a commonlace opening for an essay. But then Thomas goes on to wonder whether molecular biologists could have achieved this, if they had been flown from another planet to start life off on Earth. Suddenly comes the refreshing insight: "We would have made one fatal mistake: our molecule would have been perfect. Given enough time, we would have figured out how to do this, nucleotides, enzymes, and all, to make flawless, exact, copies, but it would never have occurred to us, thinking as we do, that the thing had to be able to make errors. The capacity to blunder slightly is the real marvel of DNA. Without this special attribute, we would still be anaerobic bacteria and there would be no music. . it is no accident at all that mutations occur; the molecule of DNA was ordained from the beginning to make small mistakes".

This is the source of the uniqueness of living things, of the idea of selfhood. In the Testament of Beauty Robert Bridges came to a similar conclusion along a different path. Thomas takes the scientist's path. $\mathrm{He}$ cites the self-labels of beans - the glycoproteins which may negotiate the intimate concordat between bean and nitrogen-fixing bactera; he cites the capacity of fish and mice to tell each other apart as individuals by a sense of smell; and he concludes that nucleated cells detached from the parent organism seem to be the only living units without a "sense of privacy". It is no wonder he has deep reservations about cloning human beings. of course, like any other professional biologist, he doesn't think it is likely to happen; but suppose it did: think what this would do to filial affection and paternal care; think of the terrifying prospect of raising from infancy and teaching language and discipline to a creature whose genetic constitution is exactly the same as your own. In any case, as Thomas explains, it couldn't happen because the selfhood of human beings depends not only on their genes but also on their environment, including their personal relations with other human beings, and it would be 
impossible to homogenise this environment. And it's as well it couldn't happen, for the only hope for evolution is for the race to have options to be matched against diversity. There's a deep wisdom in the phrase "trial and error"; we don't say (Thomas reminds us) "trial and rightness" or "trial and triumph".

One theme in these essays is to praise uniqueness. The other is to praise symbiosis and cooperation. Uniqueness does not spell solitude. The individuals cannot express their selfhood except in some sort of communication with other individuals. The committee, the quorum, the consortium, the working party: these are not specifically human devices for overlook another principle governing Nature, namely that decisions, whether consciously made by human beings or unconsciously reached by the mechanism of evolution, are the results of conflicts; and to hold a conflict one has to have an arena, even if it is a committee room.

I have space only to mention a few other flashes of illumination in the book. Thomas knows a lot about linguistics and he points out the difficulties of discussing the meanings of words when the tool for research is words themselves. There is a sort of Heisenberg ef fect which may distort the argument. Over the applications of science to medicine he is an unashamed optimist. He deplores the American

\section{Sorry, for copyright reasons some images on this page may not be available online}

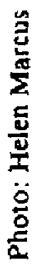

getting things done - they were invented long before by all manner of lowly organisms. Collaboration between organisms of the same kind and symbiosis between organisms of different kinds are so widespread that it leads Thomas to say that "the committee is the basis of terrestrial life". This carries him, at a safe distance from sociobiological analogies, to a discussion of the behaviour of committees of human beings. He has some penetrating things to say about the way we behave on committees. Each member, being unique, "is necessarily an actor, uncontrollably acting out the part of himself, reading the lines that identify him, asserting his identity". This is an obstacle to the efficacy of human committees, not shared by consortia of ants or termites. Each member's function, Thomas says, is to talk, "and while other people were talking the individual member was busy figuring out what he ought to say next in order to shore up his own original position". With more confidence than l myself have, Thomas advocates the Delphi technique invented by the Rand Corporation. His support for it rests on good grounds, namely that the members don't meet; instead they fill out a succession of forms, on which their views are (so it is hoped) modified by the written views of other members of the group. Hence the group members are not in competition to uphold their selfhood; instead they have time to think. Well, perhaps so. But this is surely to obsession with health: "Get a check-up. Go on a diet. Meditate, Jog". Jogging particularly riles him: "swarms of people, out onto the streets each day in underpants, moving in a stolid sort of rapid trudge, hoping by this to stay alive'". Why have people lost confidence in the human body, which has survived plague, starvation, pathogens, and is now better protected from these than ever before in all history? Thomas attributes this obsession in part to the ministrations of an immensely costly health care service.

The book, as I said, is about its author. The scientific content is merely the fuel which ignites his imagination. The personality that emerges is not entirely consistent nor is the argument always entirely logical. Thomas himself will, I think, welcome this comment, for in an essay about schizophrenics he protests that far from being a dreadful thing to have more than one self, it can (if the selves do not crowd into the body at the same time) be a rich experience; and indeed Thomas confesses to being several selves, so he would not wish to be thought to be consistent. And as for logic, Freud had the answer to that one: "Only in logic are contradictions unable to exist; in feelings they quite happily continue alongside one

Lord Ashby is Chancellor of Queen's University, Belfast, and a Fellow of Clare College, Cambridge, UK. another".

\section{LI:W} First lave JANUARY 1980 AOIn SURPAGES Editor-in-Chief: P. Somasundaran, N.Y. This new joumal is devoted to applications and principles of colloid and interface science. Areas, topics and subjects covered include emulsions, foams, aerosols, detergency and wetting, flocculation and dispersion, rheology, cosmetics, paints, foods, paper and pulp, electrokinetic and electrode phenomena, friction and lubrication, thin films, liquid membranes and bilayers, biomaterials and biocolloids, polymer colloids, pharmaceutical and related health sciences, environmental and aquatic systems, water treatment and dewatering, agricultural and soil science, minerals extraction and metallurgy. precipitation and crystal growth and modification.

\section{Of interest to:}

- mineral processors

- petroleum engineers

- soap, cosmetic and textile scientists

- bioengineers

- surface and colloid scientists

- powder technologists

- tribologists

1980: Volume 1 (in 4 issues), $\$ 81.00 / D f 1.166 .00$ including postage

Write for details or a free sample copy to

Elsevier Scientific Publishing Company, Dept. CLS, P.O. Box 330, 1000 AH Amsterdam, The Netherlands or Elsevier/North Holland Inc., 52 Vanderbilt Avenue, New York, NY10017, U.S.A. Tel: (212) 867-9040

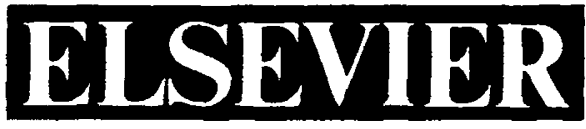

